\title{
Adoption of Ubiquitous CRM for Operational Sustainability of the Firms: Moderating Role of Technology Turbulence
}

\author{
Sheshadri Chatterjee ${ }^{1}{ }^{(}$, Ranjan Chaudhuri ${ }^{2}{ }^{(}$, Antonino Galati ${ }^{3, *(1)}$ and Demetris Vrontis ${ }^{4}(\mathbb{D}$ \\ 1 Department of Computer Science \& Engineering, Indian Institute of Technology Kharagpur, \\ Kharagpur 721302, India; sheshadri.academic@gmail.com \\ 2 National Institute of Industrial Engineering, Mumbai 400087, India; ranjan@nitie.ac.in \\ 3 Department of Agricultural, Food and Forest Sciences, University of Palermo, 90128 Palermo, Italy \\ 4 School of Business, University of Nicosia, Nicosia 1700, Cyprus; vrontis.d@unic.ac.cy \\ * Correspondence: antonino.galati@unipa.it
}

Citation: Chatterjee, S.; Chaudhuri,

R.; Galati, A.; Vrontis, D. Adoption of

Ubiquitous CRM for Operational

Sustainability of the Firms:

Moderating Role of Technology

Turbulence. Sustainability 2021, 13,

10358. https://doi.org/10.3390/

su131810358

Academic Editor: Lorenzo Ardito

Received: 2 August 2021

Accepted: 13 September 2021

Published: 16 September 2021

Publisher's Note: MDPI stays neutral with regard to jurisdictional claims in published maps and institutional affiliations.

Copyright: (c) 2021 by the authors. Licensee MDPI, Basel, Switzerland. This article is an open access article distributed under the terms and conditions of the Creative Commons Attribution (CC BY) license (https:/ / creativecommons.org/licenses/by/ $4.0 /)$.

\begin{abstract}
Ubiquitous CRM (UCRM) enhances customer relationship management. It can sense customer needs and demands, to which firms can respond quickly. Therefore, UCRM helps to improve a firm's agility. There is a growing interest among researchers and practitioners to understand how the adoption of UCRM impacts the sustainability of firms' operations, but not many studies have investigated this issue. In this context, the aim of this study is to examine how firms' absorptive capacity and dynamic capability could impact the adoption of UCRM to influence the operational sustainability of the firms and their performance. The study also investigates the moderating role of technology turbulence on the relationship between a firm's operational sustainability and its performance. Using absorptive capacity theory and dynamic capability view theory and reviewing the existing literature, we developed a conceptual model. The model was then validated using a structural equation modeling technique considering 309 usable respondents from different firms that use UCRM for their operational activities. The study found that firms' absorptive capacity and dynamic capability significantly and positively impact the adoption of UCRM, which in turn significantly and positively impacts firms' operational sustainability and improves their performance. The study also shows that there is a significant moderating role of technology turbulence on the relationship between operational sustainability and firm performance.
\end{abstract}

Keywords: absorptive capacity; dynamic capability; ubiquitous CRM; operational sustainability; firm performance; technology turbulence

\section{Introduction}

It is known that, while conventional e-commerce runs on fixed networks, ubiquitous commerce possesses some unique features, including proactiveness, mobility, context awareness, and embeddedness, along with the characteristics of business model fit. These specialties add to promptness and timeliness, compared to the legacy system [1]. Ubiquity can be interpreted as the state of being everywhere at once with any device or on any network. In the context of the customer-firm business paradigm, the firms' strong desire to synthesize customer behavior has dramatically changed the retail landscape [2]. This sense has been developed through its assimilation with the concept of pervasive technology [3].

By ensuring augmented reality $(A R)$ along with a quick response $(Q R)$, firms have been able to come close to potential customers. These mechanisms have enabled the firms to successfully reach customers' touch points through internet-connected smartphones and personal computers. This type of ubiquitous retailing (UR), with the firm's use of ubiquitous dynamic applications to improve customer relationship management (CRM), is called UCRM [4]. To be able to interact with UCRM, firms must have an appropriate capacity to absorb external knowledge with the help of their dynamic capabilities [5-8]. Thus, for operational activities to be successful when using UCRM, firms' absorptive and 
dynamic capabilities play critical roles $[9,10]$. However, these initiatives of technological development are negatively affected by the technological turbulence (TT), which determine unpredictability affecting the firm's performance. The extant literature appears to have investigated how firms could improve their performance by utilizing traditional CRM [11-13], but there are a few studies on how a firm using absorptive capacity and dynamic capability can improve its performance by extensively using UCRM. From this perspective, this study has taken a holistic attempt to address the following salient objectives:

i. To determine the role of the firms' absorptive capacity and dynamic capability in adopting $\mathrm{UCRM}^{\prime}$

ii. To examine the impact of adoption of UCRM on the firms' operational sustainability; iii. To investigate the moderating role of technology turbulence on the relationship between operational sustainability and firm performance.

\section{Literature Review}

UCRM is closely related to the concept of ubiquitous computing (UC), which includes using information technology (IT) as well as computer power. This ability has favorably affected all business sectors, especially the industrial sector [14]. The technologies of UC include smartphones, intelligent accessories, and advanced computers [3].

To achieve sustainability in processes and practices that improve a firm's performance in the current volatile, dynamic market environment, a firm must depend on its absorptive and dynamic capabilities [15,16], its market-orientation ability [17], as well as its strategic flexibility [18]. These qualities are also salient attributes of UCRM [19]. Chan et al. [20] highlighted that a firm that has efficient absorptive and dynamic abilities to appropriately apply UCRM could exhibit better firm performance. UCRM consists of using CRM with an intelligent technological system [8]. In this context, an AI-integrated CRM system can help a firm to become closer to customers' touch points than conventional contact with a salesperson, as AI can accurately analyze the customer data that the firm requires to frame its business strategy for improving operational sustainability [21-25], giving several benefits to the customer, as well as to the online merchant.

It has been observed that by improving the absorptive capacity and dynamic capability, a firm can improve its operational performance [26,27]. Operational performance is referred to as the net outcome of a firm's overall processes and practices, including production cycle time, reliability, as well as inventory turnover, which involves measure of market share and satisfaction level of the customers [28-30]. All firms strive to manufacture products at a low cost and that are high quality and to provide superior customer service [31,32]. Firms always try to meet the competitive customer demands by implementing innovative management practices, advanced manufacturing technology, and high-quality products that are delivered efficiently to the customers $[33,34]$. These age-old targets are perceived to be accomplished if a firm takes advantage of UCRM [4]. However, the rapid development of technology invites the menace of technology turbulence, which impedes firms from exhibiting better performance even after they achieve better operational sustainability $[35,36]$. Therefore, technology turbulence also needs to be addressed to ensure effective firm performance [37,38].

\section{Theoretical Background and Hypotheses Development}

\subsection{Theoretical Background}

Modern technologies can help transform the process from e-CRM, related to all Customer Relationship Management functions and forms based on information technologies, to UCRM [4]. For this, firms must have the ability to search, select, and configure the resources to meet the dynamic challenges of the market when customer demands are undergoing rapid changes [39]. Thus, for firms to adopt UCRM to improve sustainability in the context of reorientating and restructuring the processes and practices in the dynamic market to satisfy customers, they need develop their dynamic capability. 
Teece et al. [40] initially described the concept of dynamic capability as the ability of a firm to integrate, build, and reconfigure its internal as well as external expertise to combat a rapidly changing market. This is the core idea behind dynamic capability view theory $[39,40]$. Dynamic capability is considered a process through which a firm reconfigures its resources to react to market changes [41,42]. With dynamic capability, a firm search for and selects an alternative solution [43], which it shares with stakeholders. When a firm reconfigures its resources, it predicts how to augment a change through the alterations [39].

This organizational theory says that dynamic capability is a firm's capability to acquire the competence to improve its proactiveness, mobility, context-awareness, and embeddedness in order to successfully adopt UCRM. Such capabilities help the firm to implement ubiquitous retailing [1]. As already mentioned, firms must possess dynamic capabilities in the market to continuously and quickly respond to customers' changing needs and demands so that they can reach customers' touch points in a fast way compared to conventional means by ensuring augmented reality [15].

In the context of being able to improve firms' timeliness in responding to customers' demands, in real time, firms need to be able to appropriately absorb the intricacies of new technologies to successfully implement UCRM. From this perspective, their absorptive capacity plays a critical role [43-45]. In terms of the absorptive capacity [46], a firm's dynamic absorptive capacity is interpreted as "a set of organizational routines and processes by which firms acquire, assimilate, transform, and exploit knowledge to produce a dynamic organizational capability" [47]. Thus, absorptive capacity may be considered a fundamental dynamic ability in terms of a firm's competence to innovate and to aptly adopt and use UCRM by assimilating beneficial external knowledge [48-51]. Hence, it can be perceived that a firm's absorptive capacity, as well as its dynamic capability, may influence it to adopt UCRM to better impact its operational sustainability, which is perceived to improve performance.

With the inputs from the literature review and the theoretical background, a conceptual model is proposed, and it is shown in Figure 1.

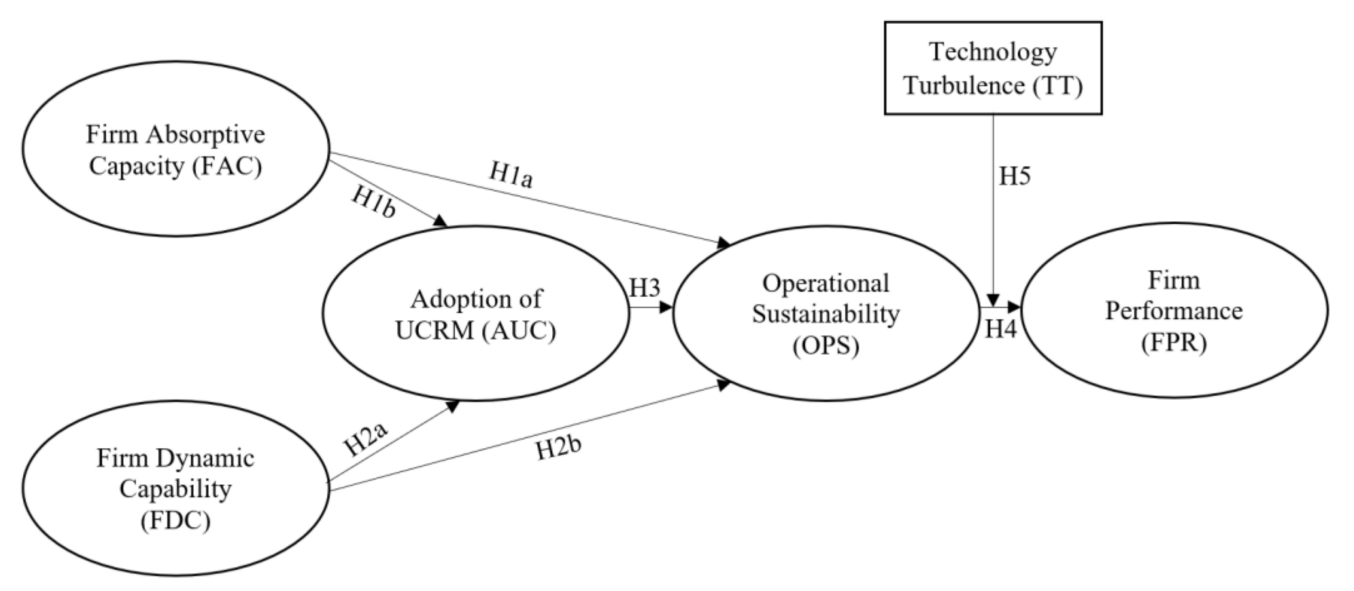

Figure 1. The conceptual model.

Here, since FAC and FDC do not depend on any variable, they are considered as independent variables, whereas AUC, OPS, and FPR are considered as dependent variables.

\subsection{Development of Hypotheses}

From the inputs of the literature review and from the knowledge of the DCV theory as well as absorptive capacity theory, the authors argue that absorptive capacity and dynamic capability of a firm impact to adopt UCRM, that in turn, could impact firm performance mediating through operational sustainability duly influenced by the moderator of technology turbulence (TT). In the subsequent subsections, the main factors which could impact 
on firm performance when UCRM is adopted will be discussed, and the relative hypothesis will be formulated.

\subsubsection{Firm Absorptive Capacity (FAC)}

Absorptive capacity is related to skill accumulation, learning processes, and the transfer of knowledge, which strengthen the potential of the firms to effectively explore knowledge sources and adapt to changes in the business environment. This capacity can help to improve firms' innovativeness [52]. Absorptive capacity is considered a fundamental dynamic ability of a firm that helps it to assimilate, share, and explore new external knowledge [47,48]. Assimilating external knowledge is perceived to be an indispensable competence of a firm for gaining innovative commercialization [53,54]. The innovation process, in the context of adopting UCRM that is comprised of modern technology applications, is perceived to be predominantly contingent on external information sources [46]. Absorptive capacity includes gaining, adapting, renovating, and developing knowledge $[55,56]$. Unless a firm completes these four steps, it is not expected to adopt and use any modern technology to proactively and quickly become successful at reaching the touch points of potential customers [57]. Through such a process to acquire knowledge to become technologically savvy, a firm is perceived to improve its processes and practices. Accordingly, it is hypothesized as follows:

Hypothesis 1a (H1a). A firm's absorptive capacity (FAC) positively impacts its operational sustainability (OPS).

Hypothesis $\mathbf{1 b}$ (H1b). A firm's absorptive capacity (FAC) positively impacts the adoption of UCRM (AUC).

\subsubsection{Firm Dynamic Capability (FDC)}

A firm's dynamic capability is conceptualized as its ability to build, integrate, and reconfigure internal as well as external capabilities in order to address the market environment that is undergoing rapid change [40]. The dynamic capability of a firm can be defined as "high level routine (or collection of routines) that, together with its implementing input flows, confer upon an organizations' management a set of decision options for providing significant outputs of a particular type" [58] (p. 991). Dynamic capability is also called higher-order capability that effects the firms' operational sustainability to enjoy its competitive advantage in a highly dynamic changing environment [59].

Several explanations of firms' dynamic capability are found in the management literature. For example, three attributes have been identified as important: sensing, seizing, and reconfiguring/transforming. A firm's capability to identify, develop, codevelop, and assess technological opportunities that could meet customers' needs and the firms' business opportunities is known as the sensing ability. A firm's ability to appropriately mobilize the external resources to meet customer needs and to improve operational sustainability by adopting new technology is called the seizing ability. In addition, a firm's ability to reconfigure or transform capabilities to encompass all activities is another attribute its dynamic capability [60]. All these capabilities are dynamic in nature, and they help a firm to adopt a new technology such as UCRM to add promptness to meeting customer needs $[1,61,62]$. Accordingly, the following hypotheses are proposed:

Hypothesis 2a (H2a). A firm's dynamic capability (FDC) positively impacts adoption of UCRM (AUC).

Hypothesis $\mathbf{2 b} \mathbf{( H 2 b ) . ~ A ~ f i r m ' s ~ d y n a m i c ~ c a p a b i l i t y ~ ( F D C ) ~ p o s i t i v e l y ~ i m p a c t s ~ i t s ~ o p e r a t i o n a l ~}$ sustainability (OPS). 


\subsubsection{Adoption of UCRM (AUC)}

Applications of ubiquitous retailing with advanced technology have helped firms to reach customers' touch points. Techno-powered customers have also grown closer to firms that use ubiquitous retailing. Using ubiquitous retailing to improve CRM is interpreted as UCRM [4]. Several studies demonstrate that the adoption of UCRM creates some operational benefits and in particular improves the operational performance through more effective cooperation and collaboration in a competitive environment $[4,8,12,63]$. Firms applying UCRM become more agile, responsible, and responsive to the customers whose demands are ever-changing in the dynamic market [63].

Firms using UCRM are more technologically savvy in interacting with the customers. However, their employees' technological competencies need to be enhanced so that they do not face any problem using UCRM [5,7]. UCRM deals with customers' basic information, including their likes and dislikes (behavioral aspects of customers), as well as sales information. UCRM also deals with customers' logical behavior, as well as physical contextual data, such as information on customers' current activities and customers' profile information. UCRM can provide real-time recommendation services [64]. Firms applying UCRM are expected to update their practices and procedures, such as responding to trends in real time, improving data management, empowering staff, and so on [65]. Accordingly, it is hypothesized as follows:

Hypothesis 3 (H3). Adoption of UCRM (AUC) positively impacts firms' operational sustainability (OPS).

\subsubsection{Operational Sustainability (OPS) and Firm Performance (FPR)}

Operational sustainability is considered to be the outcome of a process that evaluates whether a business can effectively maintain the existing practices without putting future resources at stake [66]. In this context, the concept of sustainability can be referred to as any one of the three dimensions, not only to ecological resources but also to social or economic resources. Sustainability mainly focuses on meeting the needs of the present without compromising the needs of the future [67]. Other researchers have argued that sustainability increases productivity at lower cost and increases business ability [68-70]. A study has documented that the sustainability of a firm has an impact on the performance of a firm [71]. However, as Malesios and colleagues [72] found, only specific practices and performances focused on environmental, social, and operational sustainability seem to benefit SMEs' economic performance. The opportunity to improve the firm's performance is in this specific case linked to the development of internal skills and talents within the firm capable of effectively and promptly managing relationships with clients through UCRM, as well as by adopting sustainable solutions and solving operational problems [73].

Presently, firms collect customer data to understand customers' needs, which is the principal capability of CRM. However, UCRM also realizes the behavioral trend of customers in real time, and as such, this endeavor is perceived to influence a firm's performance [74]. Firms using UCRM can develop sustainability by timely responding to customers, which would attract more customers, thus yielding more profitability and impacting performance [75]. As Obrenovic and colleagues [76] point out, firms with advanced digital systems and internet technologies sustain and manage business operations with maximum efficiency and will be able to support their operations in the long term thanks to the ability to adapt, evolve and stimulate innovation. Accordingly, it is hypothesized as follows:

Hypothesis 4 (H4). Operational sustainability (OPS) positively impacts firm performance (FPR). 


\subsubsection{Moderating Effects of Technology Turbulence (TT)}

Technology turbulence (TT) is concerned with the issues of the employees who face the dilemma of rapid change (advancement) of technology. TT has been considered as a variable moderating the relationship between operational sustainability and firm performance covered by the Hypothesis $\mathrm{H} 4$ (OPS $\rightarrow \mathrm{FRP}$ ). When there is a relationship between two constructs and when this relationship is not fixed, a third variable impacting the relationship might facilitate the strength of the relationship or can weaken the relationship, and even in some cases, it can reverse the direction of the relationship. This third variable is the moderating variable. In the present study, since the TT is known to have a negative effect towards adopting a new technology [36], the TT is perceived to impede the relationship between OPS and FPR. As such, in the present study, TT has been perceived to act as a moderating variable weakening the relationship between OPS and FPR. Technology turbulence (TT) is conceptualized as an impediment in the advancement of technology [36]. Initiatives in technological development are adversely affected by technology turbulence, which lowers the speed of technological growth [35]. Technology turbulence affects frequent changes in processes and it causes unpredictability [38]. It also impacts on practices that firms follow for technological changes [37] and affects the alteration of new products [77]. With digital knowledge, firms proceed to utilize UCRM to provide better services to attract potential customers, but technology turbulence is found to stand in the way [78-80]. It is perceived to have a negative effect on the relationship between firm performance, which is impacted by applications of UCRM, and its predictor. To address this turbulence, firms need to be more flexible. Accordingly, it is hypothesized as follows:

Hypothesis 5 (H5). Technology turbulence (TT) has a moderating influence on the relationship between operational sustainability (OPS) and firm performance (FPR).

\section{Materials and Methods}

To test the hypotheses, we conducted a survey to collect data from usable respondents. This method is useful and effective for studies that describe a population by developing suitable measurement scales and then developing a theoretical model for validation.

\subsection{Research Instruments}

From the inputs of the existing validated scale and from the knowledge of literature as well as theories, we initially prepared 32 instruments to measure the constructs to confirm content validity. A series of rectification steps were taken to correct the wordings and comprehensiveness of these instruments. The process followed was recommended by Carpenter [81]. First, the questions were pretested to correct their wordings and understandability. We then sought the opinions of 10 experts in the domain of this study to rectify any imperfections of the 32 items. A few items were corrected after the experts' inputs. All the items were prepared in the form of statements, and attention was given to see that the items were not ambiguous. The dimensions of the items were measured using a five-point Likert scale, which had anchors from strongly disagree (SD), marked as 1 , to strongly agree (SA), marked as 5 . The items were prepared so that the respondents could understand the items properly. In this way, 32 items were fine-tuned. Details of the instruments are provided in the Appendix A with source code.

\subsection{Data Collection}

Since the concept of UCRM is not old, the purposive sampling technique was adopted to recruit usable respondents for the survey. Three metropolitan cities of India were selected: Ahmadabad, Bengaluru, and Mumbai. Some of the firms in these cities use technology systems from the US, South Korea, and Japan for their UCRM. The authors of the study also knew a few of these firms.

In this way, initially, 35 firms operating with UCRM were selected. Their top executives were contacted by telephone and email and requested to allow their managers of different 
hierarchies to participate in the survey. They were also informed that the aim of this study was purely academic, and the anonymity and confidentiality of the participants in the survey would be preserved. After persuasion, eventually, the top executives of 27 firms allowed their managers to participate in the survey. The ethics protocol followed in this study is in accordance with the guidelines of the authors' respective institutes.

A list of managers of different ranks with their detailed contacts was procured from these 27 firms. There was a total of 631 respondents, and they were provided with a response sheet on which each respondent was to put one tick mark in 1 out of 5 options for each question. We also gave them a guideline on how to complete the response sheet. They were requested to respond within two months (from January 2021 until February 2021). Within the stipulated time, 321 managers responded. The response rate was $50.8 \%$. On scrutiny of these 321 responses, 12 responses were found incomplete, and they were not considered. Therefore, the responses of 309 respondents against 32 items were considered for analysis. This is within the permissible range [82]. The demographic statistics of the 309 respondents is provided in Table 1.

Table 1. Demographic statistics $(\mathrm{N}=309)$.

\begin{tabular}{llll}
\hline Category & Item & Frequency & Percentage (\%) \\
\hline Gender & Male & 189 & 61.2 \\
& Female & 120 & 38.8 \\
Education & Graduate & 249 & 80.6 \\
\multirow{4}{*}{ Working position } & Above Graduate & 60 & 19.4 \\
& Junior Manager & 125 & 40.5 \\
& Mid-level Manager & 162 & 52.4 \\
& Senior Manager & 22 & 7.1 \\
\hline
\end{tabular}

The choice to adopt a paper survey than an online survey is that it can ensure much higher overall response rates than web questionnaire and the anonymity of the respondents. Advantages that exceed the limits of this method related to higher labor and financial investments.

\section{Analysis of Data and Results}

To validate the model and for testing the hypotheses, the partial least square structural equation modelling technique has been used. This technique has been preferred for many reasons. This technique provides accurate results by analyzing an exploratory study such as this [83]. This technique does not impose any sample restriction [84]. This technique allows us to analyze data which are not normally distributed [85]. The process is comprised of two parts. One part contains measurement model, and the second part contains hypotheses testing by SEM. In this study, Wrap PLS 6.0 has been used [86].

\subsection{Measurement Properties and Discriminant Validity Test}

To measure the content validity of each item with reference to its corresponding construct, we estimated the loading factor (LF) of each item. Then, to verify the validity, reliability, and consistency of each construct, we estimated the average variance extracted (AVE), composite reliability (CR), and Cronbach's alpha $(\alpha)$ of each construct. All the parameters were found to be within the permissible range. The results are shown in Table 2. 
Table 2. Measurement properties.

\begin{tabular}{|c|c|c|c|c|c|}
\hline Constructs/Items & LF & AVE & CR & $\alpha$ & t-Values \\
\hline FAC & & 0.87 & 0.91 & 0.94 & \\
\hline FAC1 & 0.90 & & & & 21.32 \\
\hline FAC2 & 0.95 & & & & 26.39 \\
\hline FAC3 & 0.95 & & & & 28.31 \\
\hline FAC4 & 0.97 & & & & 22.06 \\
\hline FAC5 & 0.94 & & & & 21.78 \\
\hline FAC6 & 0.89 & & & & 29.12 \\
\hline FDC & & 0.86 & 0.90 & 0.93 & \\
\hline FDC1 & 0.88 & & & & 26.17 \\
\hline FDC2 & 0.96 & & & & 31.62 \\
\hline FDC3 & 0.90 & & & & 33.40 \\
\hline FDC4 & 0.92 & & & & 30.06 \\
\hline FDC5 & 0.95 & & & & 29.17 \\
\hline FDC6 & 0.94 & & & & 26.12 \\
\hline AUC & & 0.84 & 0.88 & 0.91 & \\
\hline AUC1 & 0.97 & & & & 27.36 \\
\hline AUC2 & 0.87 & & & & 25.21 \\
\hline AUC3 & 0.89 & & & & 24.26 \\
\hline AUC4 & 0.95 & & & & 29.11 \\
\hline AUC5 & 0.90 & & & & 32.17 \\
\hline AUC6 & 0.93 & & & & 28.12 \\
\hline OPS & & 0.84 & 0.89 & 0.91 & \\
\hline OPS1 & 0.89 & & & & 26.17 \\
\hline OPS2 & 0.97 & & & & 29.21 \\
\hline OPS3 & 0.91 & & & & 26.28 \\
\hline OPS4 & 0.90 & & & & 24.12 \\
\hline OPS5 & 0.96 & & & & 26.17 \\
\hline OPS6 & 0.87 & & & & 31.11 \\
\hline FPR & & 0.86 & 0.90 & 0.94 & \\
\hline FPR1 & 0.94 & & & & 29.17 \\
\hline FPR2 & 0.88 & & & & 34.27 \\
\hline FPR3 & 0.96 & & & & 26.12 \\
\hline FPR4 & 0.90 & & & & 29.31 \\
\hline FPR5 & 0.91 & & & & 37.24 \\
\hline FPR6 & 0.93 & & & & 35.67 \\
\hline FPR7 & 0.95 & & & & 38.59 \\
\hline FPR8 & 0.97 & & & & 26.11 \\
\hline
\end{tabular}

Legend: FAC: Firm Absorptive Capacity; FDC: Firm Dynamic Capability; AUC: Adoption of UCRM; OPS: Operational Sustainability; FPR: Firm Performance.

The results transpired such that all the instruments could fully interpret the corresponding constructs, as is evident from the estimation of all the loading factors which are found to lie between 0.87 and 0.97 (Table 2), which are all greater than the threshold valued of 0.70 , indicating a strong association with the respective constructs [87].

It was observed that the square roots of all the AVEs are greater than the concerned bifactor correlation coefficients. It satisfies the Fornell and Larcker criterion [88]. The results confirm discriminant validity, and are shown in Table 3.

\subsection{Moderator Analysis (Multigroup Analysis)}

In this study, technology turbulence (TT) has been considered as a moderator impacting on the linkage H4. The moderator has been analyzed by dividing the effects of TT into two categories: strong TT and weak TT. The bootstrapping procedure with consideration of 5000 resamples was followed, and multigroup analysis (MGA) was adopted. The $p$-value differences in the effects of strong TT and weak TT on the linkage H4 are 0.03 , which is less than 0.05. This confirms that the effects of TT on the linkage H4 are significant [89].

\subsection{Effect Size f ${ }^{2}$ Test}

Effect size $\mathrm{f}^{2}$ values have been assessed to examine the extent of the contributions of exogenous variables FAC and FDC to the endogenous variables. The $\mathrm{f}^{2}$ value is considered weak if it lies between 0.020 and 0.150 ; it is medium if it lies between 0.150 and 0.350; and it is considered large if it is greater than 0.350 [90]. The results show that the effect of FAC 
on AUC is 0.259 , the effect of FAC on OPS is 0.369 , the effect of FDC on AUC is 0.111 , the effect of FDC on OPS is 0.412 , the effect of AUC on OPS is 0.213 , and the effect of OPS on FPR is 0.399 . The results are shown in Table 4.

Table 3. Discriminant validity test (Fornell and Larcker criterion).

\begin{tabular}{lllllll}
\hline Construct & FAC & FDC & AUC & OPS & FPR & AVE \\
\hline FAC & 0.93 & & & & & 0.87 \\
FDC & 0.28 & 0.92 & & & & 0.86 \\
AUC & 0.33 & 0.19 & 0.91 & & & 0.84 \\
OPS & 0.19 & 0.31 & 0.39 & 0.91 & & 0.84 \\
FPR & 0.17 & 0.26 & 0.29 & 0.35 & 0.92 & 0.86 \\
\hline
\end{tabular}

Legend: FAC: Firm Absorptive Capacity; FDC: Firm Dynamic Capability; AUC: Adoption of UCRM; OPS Operational Sustainability; FPR: Firm Performance.

Table 4. Effect size $\mathrm{f}^{2}$.

\begin{tabular}{llll}
\hline Construct & AUC & OPS & FPR \\
\hline FAC & $0.259(\mathrm{M})$ & $0.369(\mathrm{~L})$ & \\
FDC & $0.111(\mathrm{~W})$ & $0.412(\mathrm{~L})$ & $0.399(\mathrm{~L})$ \\
OPS & & $0.213(\mathrm{M})$ & \\
AUC & & &
\end{tabular}

Legend: FAC: Firm Absorptive Capacity; FDC: Firm Dynamic Capability; AUC: Adoption of UCRM; OPS Operational Sustainability; FPR: Firm Performance.

\subsection{Hypotheses Testing}

Using the blindfolding process with the bootstrapping procedure considering 5000 resamples, the cross-validated redundancy has been estimated with consideration of omission distance 5. The Stone-Geisser $Q^{2}$ value was found to be 0.062 [91-93], confirming that the model has predictive relevance.

To test the fitness of the model, some fit indices and root mean square errors (RMSE) have been estimated. The results highlight that the values of the chi square (i.e., degree of freedom, comparative fit index (CFI), normal fit index (NFI), Tucker Lewis Index (TLI), and RMSE) are 2.012, 0.944, 0.867, 0.973, and 0.029, respectively. All these estimates are within the permissible range. With this process, it was possible to compute path coefficients of different linkages, $p$-values, and $\mathrm{R}^{2}$ values. The results are shown in Table 5.

With all these inputs, the validated model is shown in Figure 2.

Table 5. Path coefficients, $\mathrm{R}^{2}$ values, $p$-values, and remarks.

\begin{tabular}{|c|c|c|c|c|}
\hline Linkages & Hypotheses & $\begin{array}{l}\mathbf{R}^{2} \text { Values/Path } \\
\text { Coefficients }\end{array}$ & $p$-Values & Remarks \\
\hline Effects on OPS & & $\mathrm{R}^{2}=0.33$ & & \\
\hline By FAC & H1a & 0.32 & $p<0.0011^{(* * *)}$ & Supported \\
\hline By FDC & $\mathrm{H} 2 \mathrm{~b}$ & 0.41 & $\left.p<0.0011^{* * *}\right)$ & Supported \\
\hline By AUC & H3 & 0.37 & $p<0.01(* *)$ & Supported \\
\hline Effects on AUC & & $\mathrm{R}^{2}=0.43$ & & \\
\hline By FAC & $\mathrm{H} 1 \mathrm{~b}$ & 0.29 & $\left.p<0.01{ }^{(* *}\right)$ & Supported \\
\hline By FDC & $\mathrm{H} 2 \mathrm{a}$ & 0.17 & $p<0.05\left(^{*}\right)$ & Supported \\
\hline Effects on FPR & & $R^{2}=0.68$ & & \\
\hline By OPS & H4 & 0.46 & $p<0.0011^{(* * *)}$ & Supported \\
\hline$(\mathrm{OPS} \rightarrow \mathrm{FPR}) \times \mathrm{TT}$ & H5 & 0.19 & $p<0.05\left(^{*}\right)$ & Supported \\
\hline
\end{tabular}

Legends: FAC: Firm Absorptive Capacity; FDC: Firm Dynamic Capability; AUC: Adoption of UCRM; OPS: Operational Sustainability; FPR: Firm Performance. ${ }^{*}$ Significant at $1 \%,{ }^{* *}$ significant at $5 \%$ and ${ }^{* * *}$ significant at $10 \%$. 


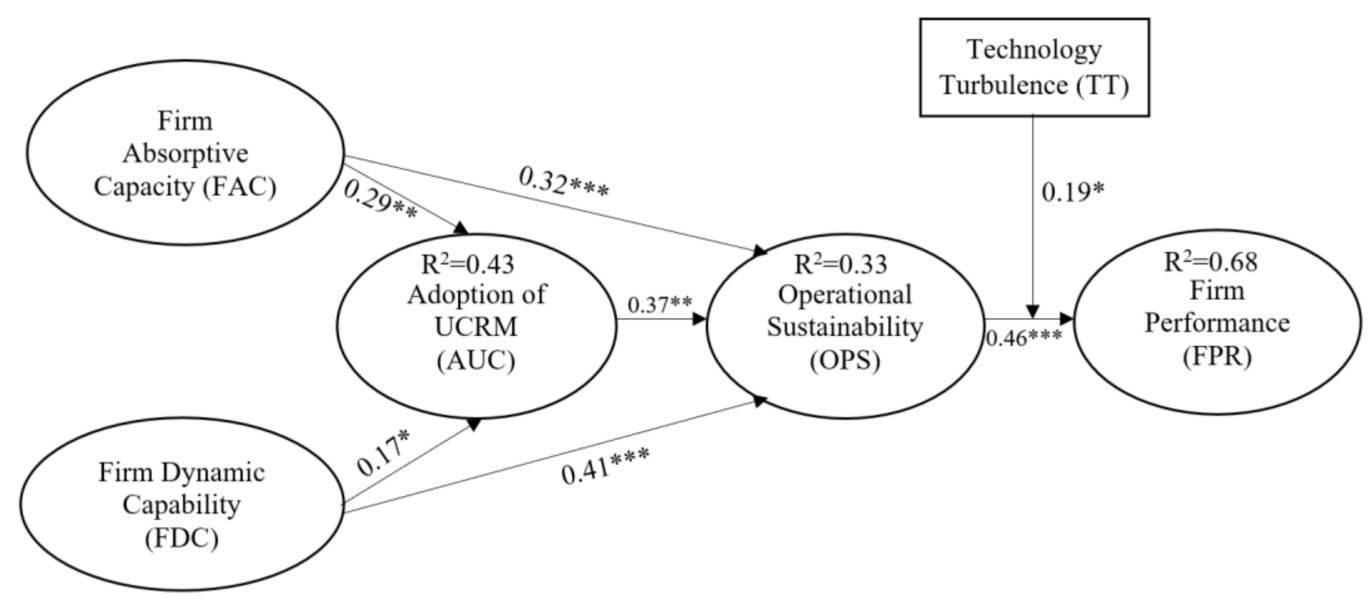

Figure 2. Validated Model (SEM). ${ }^{*}$ Significant at $1 \%,{ }^{* *}$ significant at $5 \%$ and ${ }^{* * *}$ significant at $10 \%$.

\subsection{Results}

In this study, seven hypotheses have been formulated, one of which (H5) is concerned with the impact of moderator TT on H4. Our findings show that all the variables are statistically significant. More in detail, results show that the absorptive capacity of the firm (FAC), or the ability to acquire, assimilate, transform, and exploit knowledge to create a dynamic environment, impacts both the Operational Sustainability (OPS) and the adoption of UCRM (AUC), thus confirming hypotheses $\mathrm{H} 1 \mathrm{a}$ and $\mathrm{H1}$, as the concerned path coefficients are 0.32 and 0.29 with levels of significance of $p<0.001\left(^{* * *}\right)$ and $p<0.01\left(^{* *}\right)$, respectively. In a similar way, the Firm Dynamic Capability (FDC) affects the adoption of UCRM and the Operational Sustainability, as the concerned path coefficients are 0.17 and 0.41 with levels of significance of $p<0.05\left(^{*}\right)$ and $p<0.001\left(^{* * *}\right)$, respectively, supporting the hypotheses $\mathrm{H} 2 \mathrm{a}$ and $\mathrm{H} 2 \mathrm{~b}$. A positive effect is additionally shown with regard to the relationship between AUC and OPS, since the concerned path coefficient is 0.37 with level of significance $\left.p<0.01{ }^{* *}\right)$, confirming the Hypothesis H3. These results demonstrate that the adoption of ubiquity customer relationship management positively affect the ability of the firm to manage their practices and procedures. Consequently, the OPS impacts the Firm performance (FPR), since the concerned path coefficient is 0.46 with a level of significance of $\left.p<0.001{ }^{* * *}\right)$, supporting Hypothesis H4. Additionally, our study demonstrate the impact of the moderator TT on the linkage between the operational sustainability (OPS) and Firm performance (FPS), as the concerned path coefficient is 0.19 , with a level of significance of $p<0.05\left(^{*}\right)$. This finding demonstrates that the unpredictability linked to technological development affects the capacity of the firm the achieve a solid performance.

In terms of the coefficients of determinant $\left(\mathrm{R}^{2}\right)$, we note that FDC and FAC could explain AUC to the tune of $43 \%\left(R^{2}=0.43\right)$, whereas FAC, FDC, and AUC could explain the OPS $33 \%$ of the time $\left(R^{2}=0.33\right)$. The results also show that OPS could explain FPR to the extent of $68 \%\left(R^{2}=0.68\right)$, which is the predictive power of the model.

\section{Discussion}

The present study has highlighted that a ubiquitous computing system depends on a firm understanding its specialties and its unique characteristics, which include contextawareness, embeddedness, mobility, and proactiveness, since these qualities enhance the prompt creation of new customer relationship management areas. This study has highlighted that, to adopt such CRM embedded with ubiquitous computing, firms need to develop their absorption capacity ( $\mathrm{H} 1 \mathrm{~b})$, which will also improve their practices and procedures (H1b). Therefore, the UCRM adoption is associated with the firm's ability to assimilate, share, and explore external knowledge improving their processes and practices [47,48]. This signifies that firms must recognize, assimilate, and utilize technologies, including wearable computing technology as well as context-aware computing technology. 
This first result confirms the usefulness of the absorptive capacity theory to explain the firm behavior facing new technologies [46].

Firms fight to stay in the market, which is always changing. In such a situation, to adopt a new CRM system such as UCRM, as well as to reshape the firms' processes and procedures towards sustainability, firms must develop their dynamic capability (H2a and $\mathrm{H} 2 \mathrm{~b}$ ). Indeed, in addition to possessing the ability to absorb external knowledge, firms must have the capabilities to capitalize on this knowledge, integrating it with internal resources and reconfiguring them with the aim of achieving a competitive advantage [40,59]. This idea has been supported by Dynamic Capability View theory [40]. The present study has highlighted that the adoption of UCRM impacts the firm's operational sustainability (H3). To adopt UCRM, a firm has to preserve the information of customers' behavioral patterns, which contain physical and logical patterns. The firms can preserve customers' physical data patterns by extracting customers' contextual data, and they can preserve logical data patterns by extracting web access logs $[94,95]$. To achieve this, firms must improve their operational practices.

This study has also shown that operational sustainability positively impacts performance of the firm (H4) thanks to the ability to respond promptly to the needs and expectations of customers [74,75]. As several studies reveal, specific practices focused on the operational sustainability affect the business performance [72] thanks to the capability to manage all business operations in a fast and effective way [76]. This concept is supported by Banker et al. [33]. Obviously, the link between operational sustainability and firm performance is affected by the technology turbulence (TT), which impedes a firm's technological advancement. This concept is in consonance with other studies [37,38], according to which firms cannot ignore the technological turbulence and must respond promptly to market changes. Now, the effects of the moderator TT on the linkage H4 will be discussed and illustrated with graphs, as shown in Figure 3.

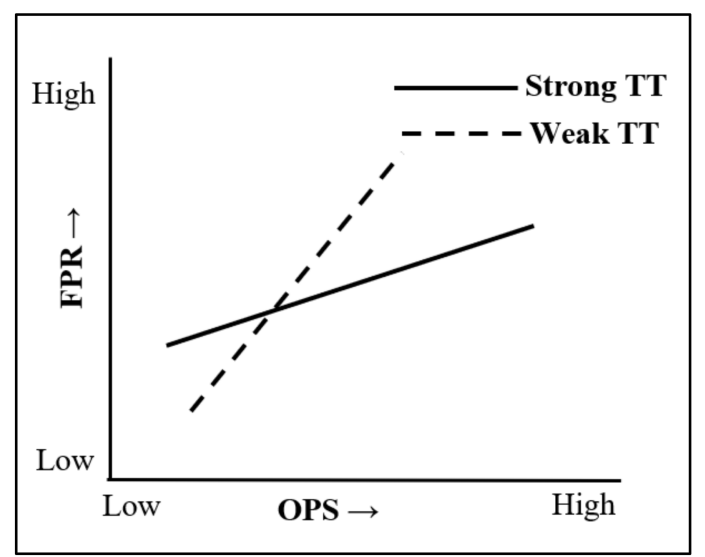

Figure 3. Effects of TT on H4.

Figure 3 represents the effects of strong TT (continuous line) and weak TT (dotted line) on the linkage $\mathrm{H} 4$ (OPS $\rightarrow$ FPR). In the graph, the gradients of the two lines signify that, as OPS increases, the rate of increase in FPR is greater from the effects of weak TT compared to the effects of strong TT, because the dotted line possesses a higher gradient.

\subsection{Theoretical Contributions}

We claim that this study has provided several theoretical contributions in the context of applications of UCRM for firms' operational sustainability. This study showed that traditional CRM now uses electronic platforms that include normal e-commerce processes, rendering them as electronic CRM or e-CRM. However, UCRM helps a firm gather sales and the basic information of customers, as well as customers' logical behavioral and physical contextual data. This study has shown how, by improving its absorptive and dynamic capabilities, a firm can achieve success by adopting UCRM that develops its operational 
sustainability and prompts firm performance. No other studies have investigated the issue of adoption of UCRM in a firm in such a way. From this perspective, we claim this study provides value to the body of knowledge.

This study basically deals with issues concerning the adoption of UCRM in a firm. Thus, to interpret and investigate such adoption, this study could have used a standard adoption model, but it has not been done. Instead, this study has used some better-suited antecedents to explain how a firm's performance can be improved by adopting UCRM. This is claimed to be a special theoretical contribution of this study.

Operational sustainability was used in this study as a mediator between the adoption of UCRM and firm performance. The authors believe that the consideration of operational sustainability as a mediating variable has strengthened the predictive power of the proposed theoretical model, thus it is a unique theoretical contribution of this study. No studies have been found that explicitly investigated the impacts of technology turbulence as a moderating variable in the context of the adoption of UCRM and its consequences. This study has effectively utilized the impacts of technology turbulence as a moderating variable and thus has been able to provide a successful theoretical model with a respectable predictive power. This is also construed to be a special theoretical contribution of this study.

\subsection{Implication to Practices}

This study hypothesized that firms' absorptive capacity positively and significantly impacts the operational sustainability (OPS) (H1a) and the adoption of UCRM (AUC) (H1b). This implies that the leaders and the managers of the firms must provide adequate opportunities for employees to participate in readiness and learning sessions, so that they learn how to recognize the contribution of a new technology, how to assimilate it, and then how to apply it. This will help employees to effectively apply different features and functionalities of UCRM. Once employees fully assimilate these UCRM capabilities, they will apply them as needed. Through such activities, employees' knowledge and skills will be enhanced, and firms will be able to improve their practices and processes to address the changing market and the dynamic needs of the customers. Such abilities will help the firms to use the appropriate resources at present without diminishing the existing resources and preserving them for their future requirements.

This study has highlighted that firms' dynamic capabilities positively and significantly impact the adoption of UCRM (H2a) and their operational sustainability (H2b). This implies that the firms' managers and leadership should always encourage and incentivize employees to learn how to sense, seize, and reconfigure any acquired knowledge and to translate that into action to benefit the firms. This will help the employees to develop dynamic capabilities, improving the adoption level of UCRM, which will improve the firms' operational structure so that they can meet customers' present needs without compromising their ability to address customers' future requirements. Therefore, firm managers and leadership should establish a conducive atmosphere so employees can work there during any challenging and dynamic business environment.

This study has also shown that the adoption of UCRM positively and significantly impacts operational sustainability (OPS) (H3), which in turn helps to improve firm performance (FPR) (H4). It implies that the managers of the firms must encourage the employees to always try to take advantage of UCRM technology so that the firms can reach the customers' touch points on a real-time basis. This will improve the firms' proactiveness and timeliness in responding to the customers' needs in the dynamic market situation. This study has highlighted that technology turbulence (TT) impacts to weaken the relationship between the operational sustainability (OPS) and firm performance (FPR). This implies that the technical team of the firms must be highly agile to address any untoward technological challenge that may arise due to the introduction of new technologies such as artificial intelligence (AI), machine learning (ML), and deep learning. There should be trained technical staff within the firms to continuously help the firms to overcome any unexpected technological challenges in the dynamic business environment. 


\subsection{Limitations and Direction to the Future Researchers}

This study has several theoretical and practical contributions. Still, it is not free from all limitations. The results of this study depend on cross-sectional data, which creates some issues in examining the causality between the constructs. It gives rise to an endogeneity problem. With longitudinal surveys duly associated with econometric analysis, future researchers may remove these shortcomings.

In this study, data were collected from firms based in India. The results so derived may not be equally applicable to other countries, and therefore, they do not possess generalizability. Future researchers may collect data from respondents spread across the world. In such cases, the results may be more generalizable. The results have been derived from the inputs of 309 usable respondents. In the global context, that number is inadequate. Future researchers may collect data from more respondents across the globe to remove this defect.

The predictive power of the model is $68 \%$. Future researchers may consider other boundary conditions for verifying whether such inclusion helps to enhance the predictive power of the model. For analyzing the study, DCV theory was considered among other theories. The DCV theory is considered to be deficient in context insensitivity [96]. In addition, DCV cannot identify the exact conditions under which FDC could better ensure the adoption of UCRM. In light of this, future research should be addressed to better understand the equilibrium between the dynamic capabilities related only to internal resources and those supported by external consultants. Furthermore, an interesting aspect to analyze is the effect of the selected variables on the adoption of UCRM and on the business performance in different geographical scenarios and industries by using a crosscountry analysis. This study did not analyze a rival model, which could help to compare the rival model with the proposed theoretical model. This could help to understand the effectiveness and veracity of the proposed model. This could have enhanced the clarity of the article. Future researchers may take this up. The present study used a blindfolding process, which can be considered as one of the limitations of this study. Future researchers may take an attempt to improve this.

Author Contributions: Conceptualization, A.G. and D.V.; methodology, S.C.; software, R.C.; validation, A.G., R.C. and D.V.; formal analysis, S.C.; investigation, R.C.; resources, D.V.; data curation, A.G.; writing—original draft preparation, S.C.; writing—review and editing, D.V.; visualization, R.C.; supervision, D.V.; project administration, R.C. All authors have read and agreed to the published version of the manuscript.

Funding: This research received no external funding.

Institutional Review Board Statement: Not applicable.

Informed Consent Statement: Not applicable.

Data Availability Statement: Collected data can be requested to the authors.

Conflicts of Interest: The authors declare no conflict of interest.

\section{Appendix A}

Table A1. Summary of Questionnaire.

\begin{tabular}{|c|c|c|c|}
\hline Items/Codes & Source & Statements & $\begin{array}{c}\text { Response } \\
{[\mathrm{SD}][\mathrm{D}][\mathrm{N}][\mathrm{A}][\mathrm{SA}]} \\
\end{array}$ \\
\hline FAC1 & {$[47,52]$} & Our firm always tries to use new technology. & {$[1][2][3][4][5]$} \\
\hline FAC2 & {$[47,48,55]$} & $\begin{array}{l}\text { Employees of our firm are adequately } \\
\text { trained to adopt new technology. }\end{array}$ & {$[1][2][3][4][5]$} \\
\hline FAC3 & {$[46,53]$} & $\begin{array}{l}\text { Our firm has required infrastructure to } \\
\text { support new technology adoption. }\end{array}$ & {$[1][2][3][4][5]$} \\
\hline FAC4 & {$[48,54,56]$} & $\begin{array}{l}\text { Our firm encourages the employees to learn } \\
\text { new tools. }\end{array}$ & {$[1][2][3][4][5]$} \\
\hline
\end{tabular}


Table A1. Cont.

\begin{tabular}{|c|c|c|c|}
\hline Items/Codes & Source & Statements & $\begin{array}{c}\text { Response } \\
{[\mathrm{SD}][\mathrm{D}][\mathrm{N}][\mathrm{A}][\mathrm{SA}]} \\
\end{array}$ \\
\hline FAC5 & {$[55,57]$} & $\begin{array}{l}\text { Our employees are well equiped to absorp } \\
\text { any new technology. }\end{array}$ & {$[1][2][3][4][5]$} \\
\hline FAC6 & {$[52,56,57]$} & $\begin{array}{l}\text { I believe that usage of a new technology } \\
\text { helps in operational sustanance. }\end{array}$ & {$[1][2][3][4][5]$} \\
\hline FDC1 & {$[40,60]$} & $\begin{array}{l}\text { Our firm has a good change } \\
\text { management capability. }\end{array}$ & {$[1][2][3][4][5]$} \\
\hline FDC2 & [58-60] & $\begin{array}{l}\text { We always try to adopt new technology as } \\
\text { soon it is available in the market. }\end{array}$ & {$[1][2][3][4][5]$} \\
\hline FDC3 & {$[1,61,62]$} & $\begin{array}{l}\text { I believe that our technology adoption speed } \\
\text { is faster than our competitors. }\end{array}$ & {$[1][2][3][4][5]$} \\
\hline FDC4 & {$[40,59]$} & $\begin{array}{l}\text { We use new tools for customer relationship } \\
\text { management activities. }\end{array}$ & {$[1][2][3][4][5]$} \\
\hline FDC5 & {$[1,61,62]$} & $\begin{array}{l}\text { I belive our firm's dynamic ability helps the } \\
\text { firm to improve operational efficiency. }\end{array}$ & {$[1][2][3][4][5]$} \\
\hline FDC6 & {$[58,62]$} & $\begin{array}{l}\text { I think that our firm has capability of quickly } \\
\text { changing as per the business needs. }\end{array}$ & {$[1][2][3][4][5]$} \\
\hline AUC1 & {$[4,63]$} & $\begin{array}{l}\text { Our firm is using ubiquitous customer } \\
\text { relationship management application. }\end{array}$ & {$[1][2][3][4][5]$} \\
\hline AUC2 & {$[4,5,65]$} & $\begin{array}{l}\text { I believe our employees are well trained to } \\
\text { use ubiquitous customer relationship } \\
\text { management application. }\end{array}$ & {$[1][2][3][4][5]$} \\
\hline AUC3 & {$[7,64]$} & $\begin{array}{l}\text { We have adequate support staff to assist } \\
\text { employees using any new application. }\end{array}$ & {$[1][2][3][4][5]$} \\
\hline AUC4 & {$[4,7,65]$} & $\begin{array}{l}\text { Our leadership team always supports the } \\
\text { usage of latest technologies. }\end{array}$ & {$[1][2][3][4][5]$} \\
\hline AUC5 & {$[64,65]$} & $\begin{array}{l}\text { I believe that ubiquitous customer } \\
\text { relationship management application helps } \\
\text { improving operational activities of our firm. }\end{array}$ & {$[1][2][3][4][5]$} \\
\hline AUC6 & [63-65] & $\begin{array}{l}\text { Our firm provides incentives to the } \\
\text { employees for using latest tools } \\
\text { and technologies. }\end{array}$ & {$[1][2][3][4][5]$} \\
\hline OPS1 & {$[66,70]$} & $\begin{array}{l}\text { I think managing better relationship with } \\
\text { customers improves sustainability. }\end{array}$ & {$[1][2][3][4][5]$} \\
\hline OPS2 & [69] & $\begin{array}{l}\text { I believe that adoption of latest technology } \\
\text { helps in improving sustainability. }\end{array}$ & {$[1][2][3][4][5]$} \\
\hline OPS3 & {$[67,68]$} & $\begin{array}{l}\text { I believe that usage of ubiquitous customer } \\
\text { relationship management improves firm's } \\
\text { operational activities. }\end{array}$ & {$[1][2][3][4][5]$} \\
\hline OPS4 & [66] & $\begin{array}{l}\text { I think that managing better relationship } \\
\text { with customers helps improving } \\
\text { customer loyalty. }\end{array}$ & {$[1][2][3][4][5]$} \\
\hline OPS5 & {$[66,69,70]$} & $\begin{array}{l}\text { Ubiquitous customer relationship } \\
\text { management brings in better collaboration. }\end{array}$ & {$[1][2][3][4][5]$} \\
\hline OPS6 & {$[67,69]$} & $\begin{array}{l}\text { I believe that ubiquitous customer } \\
\text { relationship management application helps } \\
\text { in meeting our target. }\end{array}$ & {$[1][2][3][4][5]$} \\
\hline FPR1 & {$[66,68,73]$} & $\begin{array}{l}\text { I am certain that improvement of operational } \\
\text { activities help to improve firm performance. }\end{array}$ & {$[1][2][3][4][5]$} \\
\hline FPR2 & {$[72]$} & $\begin{array}{l}\text { I believe that adoption of latest technology } \\
\text { helps in improving firm performance. }\end{array}$ & {$[1][2][3][4][5]$} \\
\hline FPR3 & [73] & $\begin{array}{l}\text { Use of ubiquitous customer relationship } \\
\text { management application can help } \\
\text { improving better revenue generation. }\end{array}$ & {$[1][2][3][4][5]$} \\
\hline FPR4 & {$[67,72,73]$} & $\begin{array}{l}\text { I believe that applications of ubiquitous } \\
\text { customer relationship management help in } \\
\text { customer retention. }\end{array}$ & {$[1][2][3][4][5]$} \\
\hline
\end{tabular}


Table A1. Cont.

\begin{tabular}{cccc}
\hline Items/Codes & Source & Statements & $\begin{array}{c}\text { Response } \\
\text { [SD][D][N][A][SA] }\end{array}$ \\
\hline FPR5 & {$[72,73]$} & $\begin{array}{c}\text { I think usage of latest technology can } \\
\text { improve firm profit. }\end{array}$ & {$[1][2][3][4][5]$} \\
FPR6 & {$[66,67]$} & $\begin{array}{c}\text { Usage of ubiquitous customer relationship } \\
\text { management applications helps in } \\
\text { improving customer delight. }\end{array}$ & {$[1][2][3][4][5]$} \\
FPR7 & {$[72]$} & $\begin{array}{c}\text { I believe that our employees are now better } \\
\text { satisfied by using latest customer } \\
\text { relationship management applications. }\end{array}$ & {$[1][2][3][4][5]$} \\
\hline FPR8 & I68,73] & $\begin{array}{c}\text { I believe that applications of ubiquitous } \\
\text { customer relationship management helps to } \\
\text { improve competativeness. }\end{array}$ & {$[1][2][3][4][5]$} \\
\hline
\end{tabular}

$\mathrm{SD}=$ Strongly Disagree; $\mathrm{D}=$ Disagree; $\mathrm{N}$ = Neither agree nor disagree; $\mathrm{A}=$ Agree; $\mathrm{SA}$ = Strongly Agree.

\section{References}

1. Kwon, O. The potential roles of context-aware computing technology in optimization based intelligent decision-making. Expert Syst. Appl. 2005, 31, 629-642. [CrossRef]

2. Narayanaswami, C.; Kruger, A.; Marmasse, N. Introduction: Pervasive retail. Pervasive Comput. 2011, 10, 16-18. [CrossRef]

3. Shayon, S. Tesco Pushes Retail Innovation with Augmented Reality. In Retail Watch; Brand Channel: Hochiminh City, Vietnam, 2011.

4. Chatterjee, S.; Ghosh, S.K.; Chaudhuri, R. Adoption of ubiquitous customer relationship management (uCRM) in enterprise: Leadership support and technological competence as moderators. J. Relatsh. Mark. 2019, 19, 75-92. [CrossRef]

5. Hameed, M.A.; Counsell, S.; Swift, S. A conceptual model for the process of IT innovation adoption in organizations. J. Eng. Technol. Manag. 2012, 29, 358-390. [CrossRef]

6. Gupta, P.; Seetharaman, A.; Raj, J.R. The usage and adoption of cloud computing by small and medium businesses. Int. J. Inf. Manag 2013, 33, 861-874. [CrossRef]

7. Trainor, K.J.; Andzulis, J.; Rapp, A.; Agnihotri, R. Social media technology usage and customer relationship performance: A capabilities-based examination of social CRM. J. Bus. Res. 2014, 67, 1201-1208. [CrossRef]

8. Chatterjee, S.; Chaudhuri, R.; Vrontis, D.; Thrassou, A. The influence of online customer reviews on customers' purchase intentions: A cross-cultural study from India and the UK. Int. J. Organ. Anal. 2021, in press. [CrossRef]

9. Maklan, S.; Knox, S. Dynamic capabilities: The missing link in CRM investments. Eur. J. Mark. 2009, 43, 1392-1410. [CrossRef]

10. de Araújo, C.C.S.; Pedron, C.D.; Bitencourt, C. Identifying and assessing the scales of dynamic capabilities: A systematic literature review. Rev. Gestão 2018, 25, 390-412. [CrossRef]

11. Nazir, S.; Pinsonneault, A. It and firm agility: An electronic integration perspective. J. Assoc. Inf. Syst. 2012, 13, 150-171. [CrossRef]

12. Chatterjee, S.; Ghosh, S.K.; Chaudhuri, R.; Chaudhuri, S. Adoption of artificial intelligence-integrated CRM system by Indian industry: From security and privacy perspective. Inf. Comput. Secur. 2021, 29, 120783. [CrossRef]

13. Galati, A.; Sakka, G.; Crescimanno, M.; Tulone, A.; Fiore, M. What is the role of social media in several overtones of CSR communication? The case of the wine industry in the Southern Italian regions. Br. Food J. 2019, 121, 856-873. [CrossRef]

14. Friedewald, M.; Raabe, O. Ubiquitous computing: An overview of technology impacts. Telemat. Inform. 2011, 28, 55-65. [CrossRef]

15. Zerbino, P.; Aloini, D.; Dulmin, R.; Mininno, V. Big data-enabled customer relationship management: A holistic approach. Inf. Process. Manag. 2018, 54, 818-846. [CrossRef]

16. Sota, S.; Chaudhry, H.; Chamaria, A.; Chauhan, A. Customer relationship management research from 2007 to 2016: An academic literature review. J. Relatsh. Mark. 2018, 17, 215-277. [CrossRef]

17. Diffley, S.; McCole, P.; Carvajal-Trujillo, E. Examining social customer relationship management among Irish hotels. Int. J. Contemp. Hosp. Manag. 2018, 30, 1072-1091. [CrossRef]

18. Dewnarain, S.; Ramkissoon, H.; Mavondo, F. Social customer relationship management: An integrated conceptual framework. J. Hosp. Mark. Manag. 2018, 28, 172-188. [CrossRef]

19. Atapattu, M.; Sedera, D. Ubiquitous Customer Relationship Management: Unforeseen Issues and Benefits. In Proceedings of the Pacific Asia Conference on Information Systems (PACIS), Hochiminh City, Vietnam, 11-15 July 2012; Pan, S.L., Cao, T.H., Eds.; AIS Electronic Library (AISeL): Hochiminh City, Vietnam, 2012. Available online: https://aisel.aisnet.org/pacis2012/187/ (accessed on 12 August 2021).

20. Chan, I.C.C.; Fong, D.K.C.; Law, R.; Fong, L.H.N. State-of-the-art social customer relationship management. Asia Pac. J. Tour. Res. 2018, 23, 423-436. [CrossRef]

21. Bose, R. Customer relationship management: Key components for IT success. Ind. Manag. Data Syst. 2002, 102, 89-97. [CrossRef] 
22. Schultz, D.; Malthouse, E.C.; Pick, D. From cm to crm to cn2: A Research Agenda for the Marketing Communications Transition. In Advances in Advertising Research; Eisend, M., Langner, T., Okazaki, S., Eds.; European Advertising Academy, Gabler Verlag: Wiesbaden, Germany, 2012; Volume 3, pp. 421-432. ISBN ISBN 978-3-8349-4291-3. [CrossRef]

23. Graca, S.S.; Barry, J.M.; Doney, P.M. Performance outcomes of behavioral attributes in buyer-supplier relationships. J. Bus. Ind. Mark. 2015, 30, 805-816. [CrossRef]

24. Fotiadis, A.K.; Vassiliadis, C. Being customer-centric through CRM metrics in the B2B market: The case of maritime shipping. J. Bus. Ind. Mark. 2017, 32, 347-356. [CrossRef]

25. Chatterjee, S.; Chaudhuri, R.; Vrontis, D.; Thrassou, A. Does "CHALTA HAI" culture negatively impacts sustainability of business firms in India? An empirical investigation. J. Asia Bus. Stud. 2021, in press. [CrossRef]

26. Kebede Adem, M.; Virdi, S.S. The effect of TQM practices on operational performance: An empirical analysis of ISO $9001: 2008$ certified manufacturing organizations in Ethiopia. TQM J. 2021, 33, 407-440. [CrossRef]

27. Chatterjee, S.; Chaudhuri, S.; Sakka, G. Apoorva, Cross-disciplinary issues in international marketing: A systematic literature review on international marketing and ethical issues. Int. Mark. Rev. 2021, in press. [CrossRef]

28. Voss, C.A.; Åhlström, P.; Blackmon, K. Benchmarking and operational performance: Some empirical results. Int. J. Oper. Prod. Manag. 1997, 17, 1046-1058. [CrossRef]

29. Grimsley, S. What Is Profitability?-Definition, Analysis \& Quiz. Available online: http://study.com/academy/lesson/what-isprofitability-definition-analysisquiz.html (accessed on 10 April 2021).

30. Chatterjee, S. Internet of Things and social platforms: An empirical analysis from Indian consumer behavioral perspective. Behav. Inf. Technol. 2018, 39, 133-149. [CrossRef]

31. Drury, C. Cost control and performance measurements in an AMT environment. Manag. Account. 1990, 25, $205-229$.

32. Kaplan, R.S.; Norton, D.P. The balanced scorecard-Measures that drive performance. Harv. Bus. Rev. 1992, 70, 71-79.

33. Banker, R.D.; Potter, G.; Schoreder, R.G. Reporting manufacturing performance measures to workers: An empirical study. J. Manag. Account. Res. 1993, 7, 33-53.

34. Das Guru, R.R.; Paulssen, M. Customers' experienced product quality: Scale development and validation. Eur. J. Mark. 2020, 54, 645-670. [CrossRef]

35. Liu, Y.; Deng, P.; Wei, J.; Ying, Y.; Tian, M. International R\&D alliances and innovation for emerging market multinationals: Roles of environmental turbulence and knowledge transfer. J. Bus. Ind. Mark. 2019, 34, 1374-1387. [CrossRef]

36. Ngamkroeckjoti, C.; Speece, M. Technology turbulence and environmental scanning in Thai food new product development. Asia Pac. J. Mark. Logist. 2008, 20, 413-432. [CrossRef]

37. Cai, W.; Wu, J.; Gu, J. From CEO passion to exploratory and exploitative innovation: The moderating roles of market and technological turbulence. Manag. Decis. 2020, 59, 1363-1385. [CrossRef]

38. dos Santos, L.L.; Borini, F.M.; Pereira, R.M. Bricolage as a path towards organizational innovativeness in times of market and technological turbulence. J. Entrep. Emerg. Econ. 2021, 13, 282-299. [CrossRef]

39. Helfat, C.E.; Finkelstein, S.; Mitchell, W.; Peteraf, M.; Singh, H.; Teece, D.; Winter, S.G. Dynamic Capabilities: Understanding Strategic Change in Organizations; John Wiley \& Sons: Hoboken, NJ, USA, 2009; ISBN ISBN: 9781405135757.

40. Teece, D.J.; Pisano, G.; Shuen, A. Dynamic capabilities and strategic management. Strateg. Manag. J. 1997, 18, 509-533. [CrossRef]

41. Eisenhardt, K.M.; Martin, J.A. Dynamic capabilities: What are they? Strateg. Manag. J. 2000, 21, 1105-1121. [CrossRef]

42. Galati, A.; Vrontis, D.; Giorlando, B.; Giacomarra, M.; Crescimanno, M. Exploring the common blockchain adoption enablers: The case of three Italian wineries. Int. J. Wine Bus. Res. 2021. ahead of print. [CrossRef]

43. Zott, C. Dynamic capabilities and the emergence of interindustry differential firm performance: Insights from a simulation study. Strateg. Manag. J. 2003, 24, 97-125. [CrossRef]

44. Wales, W.J.; Parida, V.; Patel, P.C. Too much of a good thing? Absorptive capacity, firm performance, and the moderating role of entrepreneurial orientation. Strateg. Manag. J. 2013, 34, 622-633. [CrossRef]

45. Mäkinen, S.J.; Vilkko, M.K. Product portfolio decision-making and absorptive capacity: A simulation study. J. Eng Technol. Manag. 2014, 32, 60-75. [CrossRef]

46. Cohen, W.M.; Levinthal, D.A. Absorptive capacity: A new perspective on learning and innovation. Adm. Sci. Q. 1990, 35, 128-152. [CrossRef]

47. Zahra, S.A.; George, G. Absorptive capacity: A review, reconceptualization, and extension. Acad. Manag. Rev. 2002, 27, 185-203. [CrossRef]

48. Teece, D.J. Dynamic capabilities: Routines versus entrepreneurial action. J. Manag. Stud. 2012, 49, 1395-1401. [CrossRef]

49. Ritala, P.; Olander, H.; Michailova, S.; Husted, K. Knowledge sharing, knowledge leaking and relative innovation performance: An empirical study. Technovation 2015, 35, 22-31. [CrossRef]

50. da Costa, J.C.N.; Camargo, S.M.; Machado Toaldo, A.M.; Didonet, S.R. The role of marketing capabilities, absorptive capacity, and innovation performance. Mark. Intell. Plan. 2018, 36, 410-424. [CrossRef]

51. Basit, S.; Medase, K. The diversity of knowledge sources and its impact on firm-level innovation. Eur. J. Innov. Manag. 2019, 22, 681-714. [CrossRef]

52. Noblet, J.P.; Simon, E.; Parent, R. Absorptive capacity: A proposed operationalization. Knowl. Manag. Res. Pract. 2011, 9, 367-377. [CrossRef] 
53. Egbetokun, A.A. Interactive learning and firm-level capabilities in latecomer settings: The Nigerian manufacturing industry. Technol. Forecast. Soc. Chang. 2015, 99, 231-241. [CrossRef]

54. Xia, T.; Roper, S. Unpacking open innovation: Absorptive capacity, exploratory and exploitative openness, and the growth of entrepreneurial biopharmaceutical firms. J. Small Bus. Manag 2016, 54, 931-952. [CrossRef]

55. Teece, D.J. Explicating dynamic capabilities: The nature and micro foundations of (sustainable) enterprise performance. Strateg. Manag. J. 2007, 28, 1319-1350. [CrossRef]

56. Pavlou, P.A.; El Sawy, O.A. Understanding the elusive black box of dynamic capabilities. Decis. Sci. 2011, 42, 239-273. [CrossRef]

57. Awwad, A.; Akroush, D.M.N. New product development performance success measures: An exploratory research. EuroMed J. Bus. 2016, 11, 2-29. [CrossRef]

58. Winter, S.G. Understanding dynamic capabilities. Strateg. Manag. J. 2003, 24, 991-995. [CrossRef]

59. Eckstein, D.; Goellner, M.; Blome, C.; Henke, M. The performance impact of supply chain agility and supply chain adaptability: The moderating effect of product complexity. Int. J. Prod. Res. 2015, 53, 3028-3046. [CrossRef]

60. Teece, D.J. The foundations of enterprise performance: Dynamic and ordinary capabilities in an (economic) theory of firms. Acad. Manag. Perspect. 2014, 28, 328-352. [CrossRef]

61. Wu, L.Y. Applicability of the resource-based and dynamic-capability views under environmental volatility. J. Bus. Res. 2010, 63, 27-31. [CrossRef]

62. Mikalef, P.; Pateli, A. Information technology-enabled dynamic capabilities and their indirect effect on competitive performance: Findings from PLS-SEM and fsQCA. J. Bus. Res. 2017, 70, 1-16. [CrossRef]

63. Coltman, T.; Devinney, T.M.; Midgley, D.F. Customer relationship management and firm performance. J. Inf. Technol. 2011, 26, 205-219. [CrossRef]

64. Lyytinen, K.; Yoo, Y. Issues and challenges in ubiquitous computing. Commun. ACM 2002, 45, 63-65.

65. Wang, W.; Sedera, D. A Framework for Understanding the Benefits of Supply Chain Management Systems. In Proceedings of the PACIS 2011, Brisbane, Australia, 7-11 July 2011; Volume 211.

66. Dziembala, M. The role of EU cohesion policy in promoting smart and sustainable competitiveness in the regions of the Visegrad countries. J. Sci. Technol. Policy Manag. 2011, 11, 325-341. [CrossRef]

67. Foscht, T.; Lin, Y.; Eisingerich, A.B. Blinds up or down? The influence of transparency, future orientation, and CSR on sustainable and responsible behavior. Eur. J. Mark. 2018, 52, 476-498. [CrossRef]

68. Jain, N.; Girotra, K.; Netessine, S. Managing global sourcing: Inventory performance. Manag. Sci. 2014, 60, 1202-1222. [CrossRef]

69. Liu, X.; Lee, D.; Srinivasan, K. Large-scale cross-category analysis of consumer review content on sales conversion leveraging deep learning. J. Mark. Res. 2019, 56, 918-943. [CrossRef]

70. Nguyen, H.; Calantone, R.; Krishnan, R. Influence of social media emotional word of mouth on institutional investors' decisions and firm value. Manag. Sci. 2019, 66, 887-910. [CrossRef]

71. Angus, R.W. Problemistic search distance and entrepreneurial performance. Strateg. Manag. J. 2019, 40, 2011-2023. [CrossRef]

72. Benitez-Amado, J.; Llorens-Montes, F.J.; Fernandez-Perez, V. IT impact on talent management and operational environmental sustainability. Inf. Technol. Manag. 2015, 16, 207-220. [CrossRef]

73. Malesios, C.; Skouloudis, A.; Dey, P.K.; Abdelaziz, F.B.; Kantartzis, A.; Evangelinos, K. Impact of small-and medium-sized enterprises sustainability practices and performance on economic growth from a managerial perspective: Modeling considerations and empirical analysis results. Bus. Strate. Environ. 2018, 27, 960-972. [CrossRef]

74. Akter, S.; Wamba, S.F. Big data analytics in E-commerce: A systematic review and agenda for future research. Electron. Mark. 2016, 26, 173-194. [CrossRef]

75. Ashrafi, A.; Ravasan, A.Z.; Trkman, P.; Afshari, S. The role of business analytics capabilities in bolstering firms' agility and performance. Int. J. Inf. Manag. 2019, 47, 1-15. [CrossRef]

76. Obrenovic, B.; Du, J.; Godinic, D.; Tsoy, D.; Khan, M.A.S.; Jakhongirov, I. Sustaining enterprise operations and productivity during the COVID-19 pandemic: Enterprise Effectiveness and Sustainability Model. Sustainability 2020, 12, 5981. [CrossRef]

77. Jan Hultink, E.; Atuahene-Gima, K.; Lebbink, I. Determinants of new product selling performance: An empirical examination in The Netherlands. Eur. J. Innov. Manag. 2000, 3, 27-36. [CrossRef]

78. Rosato, P.; Campo, R. Cause Related Marketing and Global Brands: How do Consumers Perceive CRM Strategies. In Research Advancements in National and Global Business Theory and Practice; Vrontis, D., Weber, Y., Tsoukatos, E., Eds.; EuroMed Academy of Business Conference Book of Proceedings; Emerald Publishing Limited: Bradford, UK, 2018; pp. 1688-1690.

79. Kefalas, S. Developing Multi-Channel Customer Relationship Management Strategy for Hotel Operation. In Research Advancements in National and Global Business Theory and Practice; Vrontis, D., Weber, Y., Tsoukatos, E., Eds.; EuroMed Academy of Business Conference Book of Proceedings; Emerald Publishing Limited: Bradford, UK, 2018; pp. 1586-1588.

80. Lee, J.W.; Khan, M.O.A. Relationships Between Innovation Management, Total Factor Productivity And Growth: A Comparative Study Between Pakistan And European Union. In Research Advancements In National And Global Business Theory And Practice; Vrontis, D., Weber, Y., Tsoukatos, E., Eds.; EuroMed Academy of Business Conference Book of Proceedings; Emerald Publishing Limited: Bradford, UK, 2018; pp. 857-869.

81. Carpenter, S. Ten steps in scale development and reporting: A guide for researchers. Commun. Methods Meas. 2018, 12, 25-44. [CrossRef] 
82. Deb, M.; Lomo-David, E. An empirical examination of customers' adoption of m-banking in India. Mark. Intell. Plan. 2014, 32, 475-494. [CrossRef]

83. Peng, D.X.; Lai, F. Using Partial Least Squares in Operations Management Research: A Practical Guideline and Summary of Past Research. J. Oper. Manag. 2012, 30, 467-480. [CrossRef]

84. Hair, J.F.; Sarstedt, M.; Ringle, C.M.; Gudergan, S.P. Advanced Issues in Partial Least Squares Structural Equation Modeling (PLS-SEM), Sage: Thousand Oaks, CA, USA, 2018; ISBN 978-14-833-7739-1.

85. Kock, N.; Hadaya, P. Minimum sample size estimation in PLS-SEM: The inverse square root and gamma-exponential methods. Inf. Syst. J. 2018, 28, 227-261. [CrossRef]

86. Wamba, S.F.; Gunasekaran, A.; Akter, S.; Dubey, R. The performance effects of big data analytics and supply chain ambidexterity: The moderating effect of environmental dynamism. Int. J. Prod. Econ. 2019, 222, 107498. [CrossRef]

87. Chin, W.W. How to Write Up and Report PLS Analyses. In Handbook of Partial Least Squares; Springer Publication: Basingstoke, UK, 2010; pp. 655-690.

88. Fornell, C.; Larcker, D.F. Evaluating structural equation models with unobservable variables and measurement error. J. Mark. Res. 1981, 18, 39-50. [CrossRef]

89. Hair, J.F.; Hult, G.T.M.; Ringle, C.; Sarstedt, M. A Primer on Partial Least Squares Structural Equation Modeling (PLS-SEM), 2nd ed.; Sage Publications: Thousand Oaks, CA, USA, 2016.

90. Cohen, J. Statistical Power Analysis for the Behavioral Sciences, 2nd ed.; Erlbaum: Hillsdale, NJ, USA, 1988.

91. Stone, M. Cross validatory choice and assessment of statistical predictions. J. R. Stat. Soc. 1974, 36, 111-147. [CrossRef]

92. Geisser, S. The predictive sample reuse method with applications. J. Am. Stat. Assoc. 1975, 70, 320-328. [CrossRef]

93. Mishra, A.; Maheswarappa, S.S.; Maity, M.; Samu, S. Adolescent's eWOM intentions: An investigation into the roles of peers, the Internet and gender. J. Bus. Res. 2019, 86, 394-405. [CrossRef]

94. Mandato, D.; Kovacs, E.; Hohl, F.; Amir-Alikhani, H. CAMP: A context-aware mobile portal. IEEE Commun. Mag. 2002, 40, 90-97. [CrossRef]

95. Bae, S.M.; Ha, S.H.; Park, S.C. Fuzzy web ad selector based on web usage mining. IEEE Expert-Intell. Syst. Their Appl. 2003, 18, 62-69.

96. Ling-Yee, L. Marketing resources and performance of exhibitor firms in trade shows: A contingent resource perspective. Ind. Mark. Manag. 2007, 36, 360-370. [CrossRef] 